\title{
Author's Preface
}

This book is a revised and slightly abbreviated form of my monograph on the rhetoric

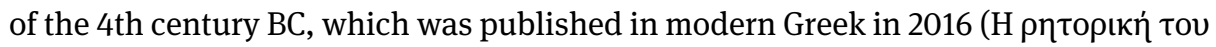

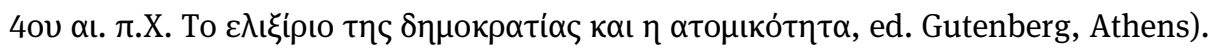
New bibliographic sources for this English edition were used only in isolated cases.

According to a chreia attributed to the philosopher Antisthenes, when a father asked him what, in his view, he ought to teach his son, Antisthenes responded: "If he is to live with the gods, philosophy; if he is to live with men, rhetoric" (Stob. Anth.

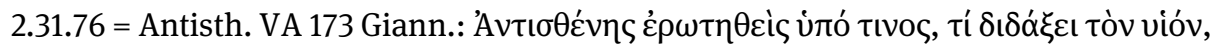

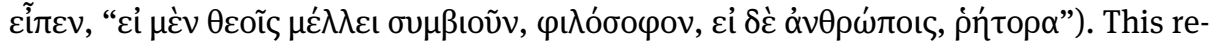
sponse may provide a simple but apt dividing line between the idealised (if not utopian) philosophical discourse and a more practical rhetoric as the component of a realistic but often contradictory human world. The central belief is that rhetoric, the art of persuasion, is integrally linked to the human community and constitutes an exceptional means of human communication.

The gift of speaking well, natural eloquence, was considered a virtue already by Homer's era, but the tremendous power of speaking was most successfully framed by Gorgias, the formidable orator and sophist of the 5th century BC: "Speech is a power-

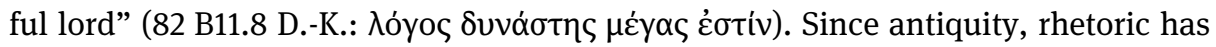
dominated almost every field of human activity: the political, the professional, the interpersonal, the literary, the scientific, the educational. For example, the need of politicians in modern parliamentary democracy to convince, to move, to enthuse, to stir anger in their audience is reflected in their handling of speaking and the acting accompanying the words. Major statesmen were deemed charismatic due to their rhetorical skills - and it is noteworthy that our contemporary diverse and liberal culture searches in the rhetoric of classical antiquity for communication models. ${ }^{1}$ The broader the freedom of speech, the more determining a factor the presence of rhetoric in public life: in this frame of mind, rhetoric and democracy are almost synonymous concepts, constituting a hendiadys.

This concerns the first part of the subtitle of this work. Rhetoric is the elixir of democracy; parrhēsia and isēgoria, the famous concept of "who wishes to speak" ( $\tau$ ís

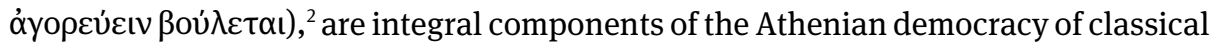
antiquity. Public speaking drives and revitalises democratic ideology. It is not that the rhetorical art ceased to play an important role during the Hellenistic or the Imperial period - far from it; since its first appearance, rhetoric has never been divorced from human activity, neither written nor verbal communication. However, its vital

1 See e.g. C. Marsh, Classical Rhetoric and Modern Public Relations. An Isocratean Model, New York 2013.

2 See Demosth. 18.170; 18.191; Aesch. 1.23; 1.27; 3.4; Aristoph. Acharn. 45; Thesmoph. 379; Eccles. 130. 
political space was the democracy of city-states, and the arrival of Hellenistic monarchy set limits and restrictions on the art. It is precisely this dimension that the second part of the subtitle refers to, the role of individuality in the 4th century BC, defined by A. Dihle as the "emancipation of the individual" (Emanzipation des Individuums). ${ }^{3}$ In the twilight of the classical period, the value system of the city-state was called upon to address individuality in a multi-factorial relationship, whether in order to curb the ambitions of high-profile individuals - both within and beyond the city walls - or in order to include them in the ideology of the city - or surmount them.

At this point, rhetoric plays a vital role as a psychagogic art, i.e. the art of "leading the souls through speech", or, as it is defined herein, "a mirror of everyday ethics": at times the orator identifies with the audience and at others distances himself from them - but what remains constant is the bipolar relationship between orator and audience, which is always vibrant and present. In no other ancient literary text is contact between the author and the audience as direct as it is in rhetorical speeches. The orator, as an individual personality, is driven by the audience, and rhetorical texts reflect the thoughts of both the orator and the audience in a two-way relationship where individuality is conversant, juxtaposed or identified with the many. Therefore, rhetorical texts serve as our best source for what K. Dover, in particular, established as "popular morality"; 4 this is a practical ethical way of thinking, a non-theoretical ethical code, whether it concerns politicians, orators or everyday individuals, such as heirs and courtesans.

A number of topics touched upon herein refer to the rhetorical texts: the dispute between rhetoric and philosophy and the central role played by Isocrates and Plato, the argument between Isocrates and Alcidamas over the primacy of the written or the spoken word, the rhetorical handbooks of Anaximenes of Lampsacus and Aristotle, the competitive ambitions of the individual and the cooperative values of the citystate, according to the classic distinction by A.W.H Adkins, ${ }^{5}$ the judicial rhetoric of Isaeus, Demosthenes, Apollodorus, Hyperides, Dinarchus and its connotations, the prosecutions of Lycurgus and the values he defends, the innovations of Isocrates and his contribution to the development of the rhetorical art, the monarchic ideology and the emergence of new states - particularly Macedon and its kings - as opposed to the "hard line" of anti-Macedonian figures such as Demosthenes, Hegesippus and Hyperides or the conciliatory and, at times, novel political directions adopted by Isocrates, Aeschines and Demades.

3 A. Dihle, Studien zur griechischen Biographie, 2. ed., Göttingen 1970, 39.

4 K. Dover, Greek Popular Morality in the Time of Plato and Aristotle, Oxford 1974.

5 A.W.H. Adkins, Merit and Responsibility. A Study in Greek Values, Oxford 1960. See also A.W.H. Adkins, Moral Values and Political Behaviour in Ancient Greece, London 1972. 
This book is based on my contribution on rhetoric in the 4th century BC to the 2nd volume of Handbuch der griechischen Literatur der Antike, edited by B. Zimmermann and A. Rengakos for the series Handbuch der Altertumswissenschaft (VII,2, ed. C.H. Beck, Munich 2014). With such a starting point, I was faced with a dilemma: should this monograph include the rhetoric of the 5th century, particularly Andocides, Antiphon and Lysias, the three orators listed in the canon of the ten Attic orators who, based on the distinction made in the German handbook, were included in the previous period? Although there are no impermeable, strictly demarcated time limits in literature or intellectual and social phenomena, in general, I finally decided not to overreach, but to focus on the rhetoric of the 4th century BC, providing merely an introductory summary of the development of this important genre until that time, making specific note of the logographer Lysias.

By following this convention, I believe I was able to further illuminate the subsequent time period, the 4th century $\mathrm{BC}$, which is often overshadowed by the 5 th century $\mathrm{BC}$ and has been far less explored. Following the recent rare (in terms of classical philology) discovery of fragments of the "New Hyperides" through the Archimedes Palimpsest, I was presented with the proposition and challenge of dedicating myself more than usual to the "minor" Attic orators of the 4th century BC, whose reception in antiquity was pitted against the masters of rhetoric, Isocrates and Demosthenes. For this purpose, various rhetorical passages were added, translated and interpreted, while I increased my focus on the interpretation of values, terms and concepts, a research area that has not benefited from systematic attention in scholarship. An effort was made to bring Isocrates, that last great sophist of the Classical era, a "rival" of Plato and a major theoretician of 4th-century rhetoric, to the forefront of the theoretical discussion of rhetoric.

At this point, I would like to express my gratitude to Professors A. Rengakos and B. Zimmermann, who entrusted me with tackling 4th-century rhetoric in the German handbook on Ancient Greek literature. Antonios Rengakos made interesting observations and, with his characteristic directness and vigour, repeatedly provided me with printed and electronic aids. I would also like to warmly thank Bernhard Zimmermann for his willingness to author a prologue to this book.

I must also thank my colleagues Kostas Apostolakis, Maria Vasiloudi, and Aggelos Kapellos, who willingly complemented gaps in my bibliography. The hospitable environment of the Library of the Department of Classics in Thessaloniki, as well as the well-endowed Libraries in Saarbrücken and Freiburg (Germany) contributed in various ways in the completion of this work. I would like to reiterate my gratitude to the Library of the American School of Classical Studies at Athens; thanks to its high standards and specifications, my need to resort to libraries abroad is always diminished. I also owe the warmest thanks to my friend and colleague Vassiliki Papathanasiou, who stood at my side throughout the duration of this endeavour, to Daniel Webber, who undertook the arduous task of translating this text into English, to the De 
Gruyter publishing house for its willingness to publish this book, and to my numerous colleagues and friends for their invaluable observations and exhortation to proceed with the English-language edition of my monograph.

Finally, I must thank my wife and children, for tolerating me all these years; deep in thoughts and with my nose buried in books, I find myself unable to record anything worthy of their love on paper. They are the ones I love the most, they know me and I know them. A few years ago, my beloved father Vassilios Alexiou passed away (19332016). He was a wonderful man, with genuine warmth and a remarkably positive attitude towards life. All I have achieved to this day, I owe to him. This book is dedicated to his memory and to that of my mother, Eleni Alexiou (1935-1993). Lastly, I would also like to dedicate this book to Maro Kavafaki; in recent years, acting with maternal affection, she has found the way to bring my internal world to the surface, to appease and soothe me, ceaselessly reminding me of my mission as a philologist.

I would like to end this preface with the hope that my study might contribute to what I call "dialectical humanism" in classical philology - that is, to the modern understanding of classics and the need to better comprehend the present through the past, far removed as such from sterile philological historicism as idealisation of antiquity. I find Nietzsche's eloquent turn of phrase in his heretical essay Wir Philologen inspiring and appropriate (transl. J.M. Kennedy):

Philology as the science of antiquity does not, of course, endure for ever; its elements are not inexhaustible. What cannot be exhausted, however, is the ever-new adaptation of one's age to antiquity; the comparison of the two. If we make it our task to understand our own age better by means of antiquity, then our task will be an everlasting one.

Thessaloniki, November 2019 Evangelos Alexiou 